\title{
Dominant feminizing mutations implicate protein-protein interactions as the main mode of regulation of the nematode sex-determining gene tra-1
}

\author{
Mario de Bono, David Zarkower, and Jonathan Hodgkin \\ Medical Research Council Laboratory of Molecular Biology, Cambridge CB2 2QH, UK
}

\begin{abstract}
The tra-1 gene is the terminal global selector of somatic sex in Caenorhabditis elegans: High tra-1 activity elicits female somatic development while low tra-1 activity elicits male development. Previous genetic studies defined a cascade of negatively interacting genes that regulates tra-1 activity in response to the primary sex-determining signal. Here, we investigate the last step in this regulatory cascade, by studying rare gain-of-function (gf) mutations of tra-1 that direct female somatic development irrespective of the upstream sex-determining signal. These mutations appear to abolish negative regulation of tra-1 in male tissues. We identify the lesions associated with 29 of these mutations and find that all affect a short stretch of amino acid residues present in both protein products of the tra-1 gene. Twenty-six alleles are associated with single nonconservative amino acid substitutions. Two alleles affect tra-1 RNA splicing and generate messages that omit part or all of the exon encoding this short stretch. These results suggest that sexual regulation of tra-1 is achieved post-translationally, by an inhibitory protein-protein interaction. The amino acid stretch altered by the tra-1(gf) mutations may define a site of interaction for negative regulators of tra-1. The stretch includes a potential phosphorylation site for glycogen synthase kinase 3 and may be conserved in the human gene GLI3, a homolog of tra-1 identified previously.
\end{abstract}

[Key Words: C. elegans; nematode; protein-protein interactions; sex determination; signal transduction; zinc fingers]

Received October 24, 1994; revised version accepted December 5, 1994

The nematode Caenorhabditis elegans occurs naturally in two sexes: the hermaphrodite, which can be thought of as a self-fertile female, and the male. Adult males and hermaphrodites differ substantially in anatomy as a result of sex-specific cell divisions, cell migrations, cell deaths, cell differentiations, and morphogenetic events that occur throughout development (Sulston and Horvitz 1977; Kimble and Hirsh 1979; Sulston et al. 1980; Sulston et al. 1983). The initial signal that determines sex is the ratio of the number of $\mathrm{X}$ chromosomes to the number of sets of autosomes, abbreviated as the $\mathrm{X} / \mathrm{A}$ ratio (Nigon 1951; Madl and Herman 1979|. In the wild, both sexes have two sets of autosomes, but worms that have $2 \mathrm{X}$ chromosomes (XX) develop as hermaphrodites whereas those that have $1 \mathrm{X}$ chromosome (XO) develop as males. Genetic studies have defined a cascade of sex-determining genes that communicates the value of the $\mathrm{X} / \mathrm{A}$ ratio to all of the developmental processes that generate sexual differences (for review, see Villeneuve and Meyer 1990; Kuwabara and Kimble 1992; Parkhurst and Meneely 1994). In the soma, these genes are thought to function as a series of negatively interacting switches that determine sex by regulating the activity of $t r a-1$, the last gene in the pathway (Fig. 1). A high X/A ratio results in high tra-1 activity, which is necessary and sufficient for female somatic development, whereas a low X/A ratio results in low tra-1 activity, which is necessary and sufficient for male development.

The 11 genes in the sex-determining pathway are genetically well characterized: All are defined by several loss-of-function (lf) mutations, including null or putative null alleles (Villeneuve and Meyer 1990). Current studies aim to elucidate the molecular mechanisms by which these genes interact. Important insights have been gained from analyses of genetic mosaics. These studies show that her-1, which occupies an intermediate position in the pathway, can function non-cell autonomously to determine sex (Hunter and Wood 1992). In contrast, tra-1, the last gene in the pathway, determines sex cell autonomously (Hunter and Wood 1990). These observations suggest that the sex-determination pathway between her-1 and tra-1 involves transmembrane cell signaling. Molecular studies of sex-determining genes support the transmembrane signaling model. The her-1 gene encodes a secreted protein of low molecular weight, designated HER-1 (Perry et al. 1993); it is abun- 
dantly transcribed in XO animals but not in XX animals (Trent et al. 1991). Immediately downstream of her-1 in the pathway is tra-2, which encodes a predicted multispan transmembrane protein, TRA-2A (Kuwabara et al. 1992). Secreted HER-1 may therefore interact directly with membrane-bound TRA-2A. Sequences have been determined for two of the fem genes: fem-1 encodes a predicted soluble protein that has six copies of the ANK repeat (Spence et al. 1990), a motif thought to mediate protein-protein interactions (Michaely and Bennett 1992); fem-3 encodes a novel soluble protein that detects no homology in the data base (Ahringer et al. 1992).

The last gene in the pathway, tra-1, has also been cloned and sequenced (Zarkower and Hodgkin 1992; Hodgkin 1993). It generates two RNA products, both of which encode predicted zinc finger proteins. The longer RNA encodes a protein with five zinc fingers /designated TRA-1A), whereas the shorter RNA encodes a carboxyterminally truncated version of TRA-1A, with only two zinc fingers (designated TRA-1B). TRA-1A, but not TRA$1 \mathrm{~B}$, binds DNA in vitro and is expected to function as a transcription regulator (Zarkower and Hodgkin 1993). The five zinc fingers encoded by tra-1 are remarkably similar to those of other proteins (up to $80 \%$ amino acid identity for fingers 3-5), including the Drosophila pattern formation genes cubitus interruptus dominant (Orenic et al. 1990) and odd-paired (Benedyk et al. 1994), the GLI family of human oncogenes and developmental regulators (Kinzler and Vogelstein 1990; Ruppert et al. 1988, 1990), and the human gene THP (Tanimura et al. 1993).

The genetic and molecular characteristics of the genes in the sex-determining cascade of $C$. elegans suggest a specific model to explain how these genes interact at the molecular level to regulate somatic sex (for review, see Kuwabara and Kimble 1992). The first step in the pathway postulates that in XO animals, abundant HER-1 binds to the predicted transmembrane protein TRA-2A, and prevents it from down-regulating FEM activity. Active FEM proteins are consequently able to down-regulate tra-1 activity by an unknown mechanism that is thought to be translational or post-translational, as no sex-specific differences in tra-1 mRNA have been detected (Zarkower and Hodgkin 1992). The absence of HER-1 in XX animals allows TRA-2A to be active. The model suggests that active TRA-2A down-regulates one or more of the FEM proteins, perhaps by binding to them directly. Low fem activity allows tra-1 to be active and to direct female somatic development, perhaps by regulating transcription.

This work investigates the mechanism by which the fem genes regulate tra-1, using a molecular genetic approach. Strong lf mutations in any of the fem genes completely feminize XO animals (Doniach and Hodgkin 1984; Kimble et al. 1984; Hodgkin 1986). Dominant gain-of-function (gf) alleles of tra-1 have been isolated that have phenotypes similar to those of fem(lf) mutations (Hodgkin 1985, 1986, 1987). These alleles behave as if they are partially or completely insensitive to negative regulation by the fem genes. By identifying the lesions associated with tra-1 (gf) alleles we hoped to elucidate the molecular mechanism by which the fem genes regulate wild type tra-1. We examined 30 tra-1(gf) alleles and find that 29 are associated with lesions that alter a small stretch of amino acid sequence common to both TRA-1 proteins. Our results suggest that sexual regulation of tra-1 is achieved post-translationally, probably by a protein-protein interaction. The thirtieth allele, the weak atypical mutation $e 2271(g f)$, affects a distinct part of the tra-1 gene that has not yet been identified.

\section{Results \\ Phenotypes of tra-1 gf mutations \\ Gain-of-function mutations of tra-1 cause dominant feminization of XO animals and abolish spermatogenesis in XX animals (Hodgkin 1980, 1987; Schedl et al 1989). Table 1 lists 30 tra-1 (gf) alleles and describes the genetic screens in which they were isolated. We compared the phenotypes of 27 of these alleles, by scoring sexually dimorphic structures in tra-1(gf)/ + XO animals (Table}

Table 1. Gain-of-function Mutations of tra-1

\begin{tabular}{|c|c|c|}
\hline tra-1 (gf) mutation & Phenotype screened for $(\text { Ref. })^{a}$ & Strain mutagenized ${ }^{\mathrm{b}}$ \\
\hline e1575 & strong feminization of $\mathrm{XO}$ animals $\{1\}$ & $\begin{array}{l}\text { him-5(e1490) dpy-21(e428) V; } \\
\quad \text { unc-7(e5) X }\end{array}$ \\
\hline e1937; e1946; e2013; e2014; e2098; oz6 & dominant feminization of XX germ line (2-4) & N2 \\
\hline$e 2065 ; e 2067 ;$ e2069; e2071 & suppression of $t r a-3 \mathrm{XX}$ infertility $(5)$ & tra-3(e1107) IV or tra-3(e1767) IV \\
\hline $\begin{array}{l}\text { e1951; e1953; e1961; e1962; 1993; e1997; } \\
\quad \text { e1998; e2009; e2097 }\end{array}$ & suppression of tra-3 XX infertility $|6|$ & fem-2(b245ts) III; tra-3(e1767) IV \\
\hline$e 2198 ; e 2271$ & suppression of tra-2 XX infertility $(7)$ & smg-2(e2008) I; tra-2(e1209) II \\
\hline$e 2109$ & suppression of egl-41 egg-laying defect (3) & $e g l-41(e 2055 s d) V$ \\
\hline$q 183 ; q 185 ; q 245$ & suppression of fem-3(gf) XX infertility (8) & fem-3(q96gf,ts) dpy-20(e1282) IV \\
\hline$e 2535 ; e 2537 ; e 2554 ; e 2579$ & strong feminization of $\mathrm{XO}$ animals $|7\rangle$ & tra-2(e2046gf) II; dpy-28(y1ts) III \\
\hline
\end{tabular}

aReferences: (1) Hodgkin (1980); (2) Doniach (1986); (3) T. Doniach (unpubl.); (4) T. Schedl (unpubl.); (5) Hodgkin (1985); (6) Hodgkin (1986); (7) J. Hodgkin (unpubl.); (8) Schedl et al. (1989).

${ }^{b}$ All alleles except $q 245$ and $o z 6$ were isolated after EMS mutagenesis; oz6 was isolated after $\gamma$-irradiation; $q 245$ arose spontaneously in a mutator strain. 
Table 2. Phenotypes of tra-1 (gf $) /+X O$ animals

\begin{tabular}{|c|c|c|c|c|c|c|c|}
\hline Class $^{a}$ & Alleles & Tail & T rays ${ }^{b}$ & $\mathrm{~V}$ rays $/ \mathrm{pal}^{\mathrm{b}, \mathrm{c}}$ & Spicules ${ }^{b}$ & $\begin{array}{l}\text { Somatic } \\
\text { gonad }\end{array}$ & Self-fertility ${ }^{\mathrm{d}}$ \\
\hline 1 & $\begin{array}{l}\text { e1575; e1937; } \\
\text { e1946; e2009; } \\
\text { e2097; e2098; } \\
\text { e2109; e2535; } \\
\text { e2537; e2554; } \\
\text { e2579; oz6 }\end{array}$ & $\begin{array}{l}\text { female; } \\
\text { healthy, } \\
\text { truncated tail } \\
\text { spike }\end{array}$ & absent & $\begin{array}{l}\mathrm{V} \text { rays absent } \\
\text { pal present }\end{array}$ & absent & female & occasional \\
\hline 2 & $\begin{array}{l}\text { e1993; e1997; } \\
\text { e2014 }\end{array}$ & $\begin{array}{l}\text { intersexual or } \\
\text { very } \\
\text { truncated tail } \\
\text { spike; } \\
\text { frequently } \\
\text { scrawny }\end{array}$ & present & $\begin{array}{l}\mathrm{V} \text { rays rarely } \\
\text { present; pal } \\
\text { occasionally } \\
\text { present }\end{array}$ & $\begin{array}{l}\text { small, } \\
\text { crumpled }\end{array}$ & female & frequent \\
\hline 3 & $\begin{array}{l}\text { e1951; e1961; } \\
\text { e1962; e1998; } \\
\text { e2069; e2071; } \\
\text { e2198 }\end{array}$ & intersexual & present & $\begin{array}{l}\text { V rays } \\
\text { occasionally } \\
\text { present; pal } \\
\text { also } \\
\text { occasionally } \\
\text { present }\end{array}$ & large, crumpled & $\begin{array}{l}\text { female; } \\
\text { occasionally } \\
\text { disorganized }\end{array}$ & frequent \\
\hline 4 & $\begin{array}{l}e 1953 ; e 2065 \\
e 2067\end{array}$ & $\begin{array}{l}\text { intersexual or } \\
\text { male }\end{array}$ & present & $\begin{array}{l}\text { usually have } \\
>4 \text { but }<8 \mathrm{~V} \\
\text { rays }\end{array}$ & large, crumpled & $\begin{array}{l}\text { female; } \\
\text { frequently } \\
\text { disorganized }\end{array}$ & occasional \\
\hline 5 & $e 2013 ; q 183$ & $\begin{array}{l}\text { male; } \\
\text { occasionally } \\
\text { exhibit } \\
\text { mating } \\
\text { behaviour }\end{array}$ & present & $\begin{array}{c}\text { usually have } \\
>8 \mathrm{~V} \text { rays }\end{array}$ & $\begin{array}{l}\text { large, } \\
\text { occasionally } \\
\text { wild type }\end{array}$ & $\begin{array}{l}\text { female; } \\
\text { frequently } \\
\text { disorganized }\end{array}$ & occasional \\
\hline
\end{tabular}

For alleles in classes 2-5 (with the exception of $q 183)$, the tra-1(gf)/ + XO animals scored were progeny of tra-1(gf); tra-3(e1767) females mated with $\mathrm{N} 2 \mathrm{XO}$ males. tra-1(q183gf)/ + XO animals were the progeny of unc-32(e189) tra-1(q183gf) XX females mated with $\mathrm{N} 2 \mathrm{XO}$ males. For alleles in class 1 , the $t r a-1(g f) /+\mathrm{XO}$ animals scored were progeny of $t r a-1(g f) /+;$ tra-3(e1767) females mated with $\mathrm{N} 2 \mathrm{XO}$ males.

${ }^{a}$ Class indicates degree of feminization, with class 1 most strongly feminizing. XO animals heterozygous for the same tra-1/gf) allele display some variation in phenotype; however, each allele can be unambiguously assigned to a class by scoring several individuals. At least 20 animals were examined for each allele.

${ }^{b} \mathrm{~V}$ rays, $\mathrm{T}$ rays, and spicules are parts of the male copulatory apparatus. $\mathrm{V}$ rays and posterior alae (pal) are generated by descendants of the same blast cells, but $\mathrm{V}$ rays are only produced in males, and pal only in hermaphrodites.

cWild-type males have $12 \mathrm{~V}$ rays.

dSelf-fertility scores the presence of embryos in utero. The viability of these embryos was not examined.

2). Some of these alleles were examined previously by Hodgkin (1987) or Schedl et al. (1989). The 27 alleles fall into a single allelic series of five phenotypic classes. Alleles in class 1 almost completely feminize XO animals in a single copy, whereas $\mathrm{XO}$ animals with a single copy of an allele in class 5 retain an almost wild-type male tail but have a female or intersexual somatic gonad and an abnormal vulva. Like wild-type tra-1, all of the alleles described in Table 2 are competent to direct complete female somatic development in XX animals when present as a single copy. No sign of masculinization can be detected in tra-1(gf)/tra-1(null) XX animals for any of these alleles (this work; Hodgkin 1987). We call these alleles "pure" gf alleles. In contrast, the tra-1 (gf) alleles $q 185$ and $q 245$ have lf as well as gf components to their phenotypes (Schedl et al. 1989). A third class of tra-1(gf) alleles is exemplified by e2271 (Zarkower et al. 1994). This allele feminizes the germ lines of XX and XO animals (Hodgkin 1987) but does not appear to feminize the
XO soma. Germ-line feminization by $e 2271$ is enhanced by lf mutations in the $s m g$ genes (smg = suppressors with morphogenetic effects on genitalia), which are thought to be part of an mRNA surveillance system that degrades aberrant mRNA (Pulak and Anderson 1993). The tra1 (gf) alleles $q 185, q 245$, and $e 2271$ have been omitted from Table 2 because of their unusual properties.

As well as feminizing the soma of XO animals, single copies of tra-1(gf) mutations abolish or reduce spermatogenesis in XX and XO animals (Table 2; Hodgkin 1987; Schedl et al. 1989). This indicates that deregulated tra-1 activity inhibits spermatogenesis or activates oogenesis. Previous studies suggested that tra-1 or a gene downstream of it may positively regulate the accumulation of tra-2 mRNA in a feedback mechanism (Okkema and Kimble 1991). It seemed possible that feminization of the XX germ line by tra-1(gf) alleles was attributable to elevated tra-2 activity. To test this, we examined animals doubly mutant for strong tra-1(gf) alleles and the 
putative null allele of tra-2, $e 1095$, for self-fertility. Selffertility is a good indicator of sperm production in $C$. elegans. Although tra-1(gf)/+; tra-2(e1095) XX animals are occasionally self-fertile, homozygous $\operatorname{tra}-1(g f) ; \operatorname{tr} a-$ 2(e1095) XX animals are female. Previously reported double mutant experiments reveal that tra-3 also is not required for feminization of the XX germ line by tra-1 (gf) mutations (Hodgkin 1987). The effect of tra-1(gf) mutations on germ line sex-determination is therefore likely to be mediated by genes other than tra-2 or tra-3, at least in part.

\section{Molecular analysis of tra-l(gf) mutations}

Genetic studies suggest that in wild-type XO animals, tra-1 is down-regulated by the three fem genes (Fig. 1; for review, see Villeneuve and Meyer 1990|. Strong lf mutations in any of these genes cause complete feminization of XO animals, as a result of constitutive tra-1 activity. The similar phenotypes of $f e m(l f)$ and tra-1/gf) mutants suggest that the lesions associated with tra-1(gf) alleles render tra-1 insensitive to down-regulation by the fem genes. Molecular analysis of these lesions may therefore shed light on the mechanism by which tra-1 and the fem genes interact. We used reverse transcription of total RNA followed by PCR (RT-PCR) to obtain tra-1 cDNA from tra-1 (gf) alleles. By sequencing this cDNA we identified the lesions associated with 29 of the 30 tra-1(gf) alleles listed in Table 1 (see Materials and methods for more details\}.

\section{7 tra-l(gf) alleles are associated with amino acid} substitutions in a small region of both TRA-1 proteins

The lesions associated with the 27 pure tra-1(gf) alleles described in Table 2 are shown in Figure 2 . All but one of these alleles are associated with single base pair changes in the fourth exon of tra-1. The exceptional allele, oz6, affects the same stretch of nucleotide sequence but has substitutions of two adjacent base pairs. The 27 alleles are associated with 10 different base pair substitutions clustered in a stretch of 48 nucleotides. Of these 10 base changes, 7 have been independently isolated multiple times, in alleles with apparently identical phenotypes (Table 2). Each base change causes nonconservative amino acid substitution of one (or 2 for oz6) of 8 amino acids in a hydrophilic stretch of 16 residues. Of the eight mutated residues, three are prolines. We have called this part of the tra-1 open reading frame the "GF region." The GF region is found in both predicted TRA-1 proteins, at amino acid positions 73-88 (Zarkower and Hodgkin 1992). Examination of the weak smg-sensitive tra-1(gf) allele $e 2271$ detects no lesions in the GF region.

The relative frequency of isolation of particular base changes reflects the mutagen used. All but 1 of the 27 alleles listed in Figure 2 were isolated after mutagenesis with ethylmethane sulfonate (EMS), which principally causes GC $\rightarrow$ AT transitions (Coulondre and Miller 1977). The two EMS-induced base changes that have been isolated only once $(e 1575, \mathrm{AT} \rightarrow \mathrm{GC}$; e1937, $\mathrm{TA} \rightarrow \mathrm{AT})$ are generated infrequently with this mutagen (Coulondre and Miller 1977). The remaining allele, oz6, was generated by $\gamma$-irradiation (T. Schedl, pers. comm.), which can induce cross-linking of adjacent pyrimidine bases (Coulondre and Miller 1977).

The tra-1 (gf) alleles $\mathrm{q} 185$ and $\mathrm{q} 245$ are associated with aberrant splicing of the region affected by the pure tra-1(gf) alleles

We examined the GF region in the two complex alleles $q 185$ and q245. These alleles are called "mixomorphic" (J. Kimble, pers. comm.), because they have both lf and gf properties.

q185 RT-PCR analysis of RNA from tra-1 (q185gf) using primers that straddle sequence encoding the GF region reproducibly yielded multiple PCR products instead of the single product generated in positive control reactions using RNA from wild-type worms (Fig. 3). Sequence analysis reveals that these multiple PCR products represent aberrantly spliced tra-1 cDNAs in which the splice donor of exon 3 does not correctly splice on to the splice acceptor site of exon 4 . The lesion responsible for this aberrant splicing is a GC $\rightarrow$ AT substitution in the splice acceptor site of exon 4 , which converts the wild-type sequence TTGCAG $\rightarrow$ TTGCAA, impairing its ability to act as a splice acceptor. This activates cryptic splice acceptor sites or induces exon skipping (Fig. 4).
Figure 1. A simplified regulatory pathway for somatic sex-determination in C. elegans, derived from epistasis analysis (for review, see Villeneuve and Meyer 1990). A cascade of negatively interacting genes regulates tra-1 activity according to the X/A ratio. A high $\mathrm{X} / \mathrm{A}$ ratio leads to high tra-1 activity and female somatic development; a low $\mathrm{X} / \mathrm{A}$ ratio leads to low tra-1 activity and male development. Genes are called after their lf phenotypes: (xol) XO lethal; $(s d c)$ sex determination and dosage compensation; (her) hermaphroditization; $($ tra $)$ transformer; and $(\mathrm{fem})$ feminization. Arrows represent activation; bars indicate inhibition. Indicated below the pathway are the activity states of sex-determining genes in XX and XO animals inferred from their lf phenotypes. 
A

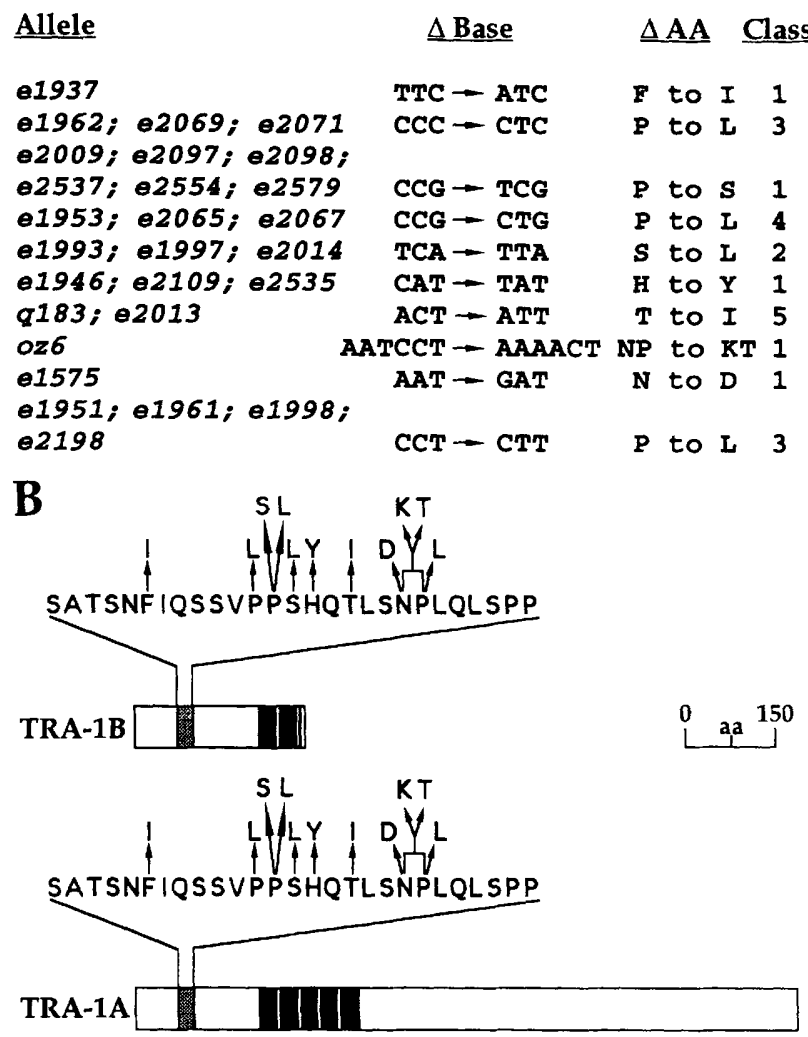

Figure 2. Molecular lesions associated with 27 gf alleles of tra-1. Each allele is associated with nonconservative amino acid substitutions in the GF region, a short stretch of sequence close to the amino terminus of both TRA-1 proteins. $(A \mid$ Base and amino acid changes associated with each allele. Alleles are listed with the most amino-terminal substitutions first. Base changes are given in the context of the codon they affect; Class refers to allele strength (see Table 2$\}.|B|$ The lesions listed in $A$ in the context of the TRA-1 proteins, which are represented by boxes. The sequence of the wild-type GF region is given using the single-letter amino acid code. The GF region extends from the phenylalanine $(F)$ residue $(l e f t)$, to the proline residue in the sequence SNPL (right). Arrows indicate the amino acid substitutions associated with different tra-1(gf) mutations. Solid boxes indicate zinc fingers; stippled boxes indicate the GF region.

Six aberrant splices have been detected in tra-1 RNA products of $q 185$, four of which have been sequenced. Two partially or completely delete the GF region, but retain the open reading frame; another inserts a single alanine residue after position 58 . The fourth (not shown in Fig. 4) uses a cryptic splice acceptor present in the intron between exons 3 and 4: this splice alters the reading frame and introduces stop codons shortly after the splice junction, upstream of the GF region. The two unsequenced aberrant products are at least $300 \mathrm{bp}$ longer than the wild-type splice product. They are almost certainly generated by splicing the splice donor site of exon 3 to cryptic splice acceptor sites in the intron between exons 3 and 4 (data not shown). Such splice products would either alter reading frame or introduce stop codons upstream of the GF region. Wild-type splicing to the mutated TTGCAA splice acceptor also occurs in tra1(q185) and generates tra-1 RNAs that are wild type.

q245 This allele was previously characterized by Southern analysis and shown to be associated with complex rearrangements around the GF region (Hodgkin 1993). PCR amplification of cDNA made from homozygous $q 245$ animals using tra-1-specific primers that straddle the rearranged region yield a low level of wildtype product and several more abundant aberrant splice products (Materials and methods; Fig. 3). Sequence analysis reveals the aberrant products detected are deleted for the GF region but retain the tra-1 open reading frame. These RNAs result either from exon skipping or from use of cryptic splice donor sites (Fig. 5, B-D). The aberrant splicing patterns suggest that the splice donor of exon 4 is disabled in tra-1(q245gf), but we do not know the precise nature of the disabling lesion.

The defective splicing patterns present in $q 185$ and q245 explain the mixture of lf and gf tra-1 phenotypes exhibited by these alleles. The gf phenotypes can be ascribed to deregulated TRA-1 proteins deleted for the GF region. The lf phenotypes are probably attributable to

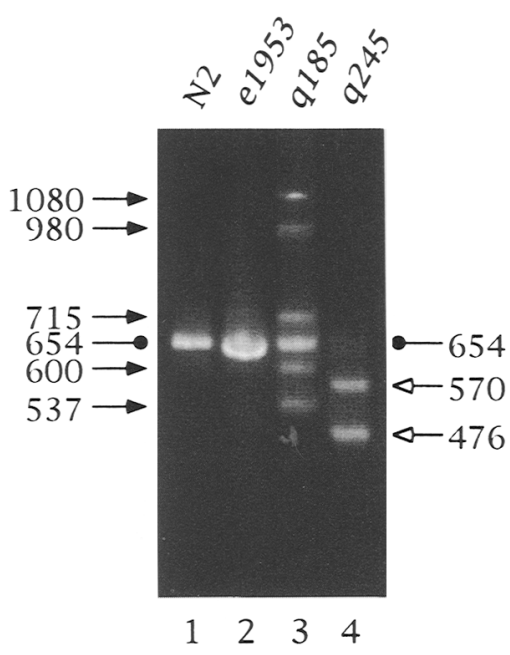

Figure 3. The unusual tra-1(gf) alleles $q 185$ and $q 245$ are associated with aberrant splicing. Total cDNA prepared from N2 (wild type, lane 1), tra-1 (e1953gf) (lane 2), tra-1 (q185gf) (lane 3), and tra-1 (q245gf) (lane 4) worms were amplified with PCR using primers DZ17 and MDB13, which straddle sequences encoding the GF region. All four CDNAs yield a PCR product of the expected wild-type size (654 bp, indicated by $)$; however, cDNA from $q 185$ and $q 245$ generate additional DNA bands that correspond to aberrant splice products (arrows). The allele $q 185$ yields six splice products of distinct sizes, indicated at left. Four of these products $(715,654,600$, and $537 \mathrm{bp})$ have been cloned and sequenced, and three are shown in detail in Fig. 4 (A and B, band at $654 \mathrm{bp}$; C, band at $600 \mathrm{bp}$; D, band at $537 \mathrm{bp}$ ). The allele $q 245$ yields two major products, indicated by open arrows at right, and shown in detail in Fig. 5, B and D ( $\sim 480 \mathrm{bp})$, and C $(570 \mathrm{bp})$. The PCR product from e1953 (lane 2) usually comigrates with the wild-type product, but migrated aberrantly in the gel shown. 
Figure 4. Splicing patterns of tra-1 RNA in tra-1(q185gf). In this allele the splice acceptor site of tra-1 exon 4 (underlined base sequence) is altered from TTGCAG to TTGCAA (downward arrow), resulting in aberrant splicing. $(A-D)$ The predominant tra-1 cDNA products detected. Bases (and corresponding amino acid residues) included in spliced products are in bold. The underlined amino acid sequence is the GF region. $(A)$ Wild-type splice; $(B \mid$ aberrant splice that adds a single alanine residue at the junction between exons 3 and 4 ; $(C)$ aberrant splice that deletes one-third of the GF region and retains frame; $(D)$ exon skipping that deletes exon 4 and retains frame. Additional splice products use cryptic splice acceptor sites in the intron between exons 3 and 4 ; these splices either generate a frameshift or introduce stop codons upstream of the GF region (not shown). An approximate estimate of the relative abundance of these splice products is shown in Fig. 3.
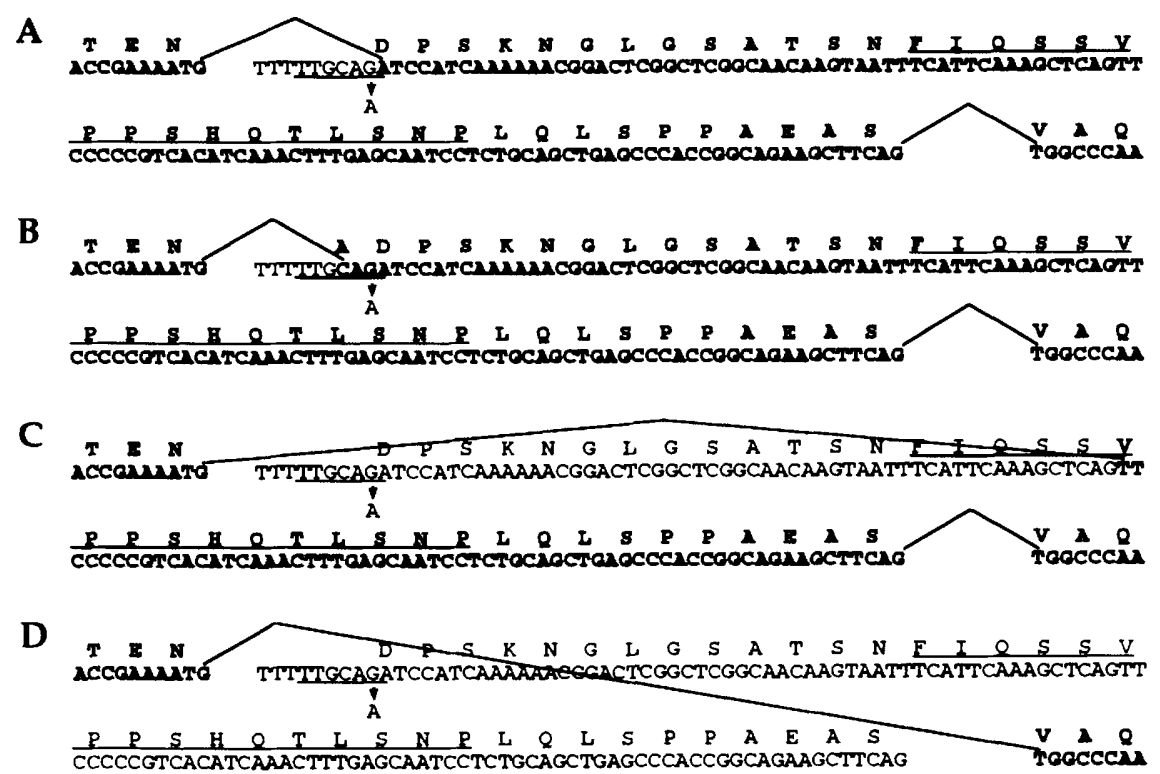

reduced overall levels of functionally spliced tra-1 mRNAs or to the deletions in the TRA-1 proteins themselves.

Mutations that disable splice acceptor sites of C. elegans genes have been identified previously in let-23 and dpy-10 (Aroian et al. 1993). At least one of these, the let-23 receptor tyrosine kinase allele $n 1045$, also appears to exhibit a mixture of lf and gf phenotypes. In these alleles, as in tra-1(q185gf), some splicing to the mutated splice acceptor sites is retained, despite the absence of the AG dinucleotide found at the $3^{\prime}$ end of almost all eukaryotic introns. Our analysis of splicing of $q 185$ RNA extends the analysis of Aroian et al. and demonstrates that C. elegans introns of $1 \mathrm{~kb}$ (the size of the intron between exons 3 and 4 of tra-1) can be spliced correctly in the absence of a $3^{\prime}$ AG dinucleotide in the splice acceptor.

\section{Discussion}

\section{Sexual regulation of tra-1 is post-translational}

Previous studies suggested that sexual regulation of tra-1 is translational or post-translational, as no sexual differences have been detected for RNAs expressed from this gene (Zarkower and Hodgkin 1992). To explore this regulation further, we identified the lesions associated with 29 gf alleles of tra-1 that are uncoupled from sexual regulation. Twenty-seven alleles correlate with nonconservative amino acid substitutions in a stretch of 16 amino acids, which we call the GF region. Another two alleles are associated with aberrant splicing, which results in deletion of the GF region. The clustering suggests that all 29 alleles disrupt the same regulatory process; the splicing mutations imply that this process is post-transcriptional. In principle, the different molecular lesions could act by deregulating tra-1 RNA metabolism: For example, the mutations might disable an inhibitory mechanism that prevents translation of tra-1 RNA. However, all 10 different base pair changes associated with the 27 pure gf alleles result in nonconservative amino acid substitutions (Fig. 2); none is silent. There are 21 possible GC $\rightarrow$ AT transitions in the 48 -bp sequence encoding the GF region. Of these transitions, 2 would result in stop codons, 6 would be silent, and 13 would result in missense mutations. Eight of the 13 missense transitions have been recovered as tra-1(gf) mutations but none of the silent transitions. This suggests that the gf phenotypes are attributable to altered TRA-1 proteins. This interpretation is supported by a comparison of the GF region of C. elegans tra-1 and C. briggsae tra-1: All 8 amino acids affected by gf mutations are identical between the two species, although the surrounding region has diverged substantially /Fig. 8, below; M. de Bono and J. Hodgkin, unpubl.|. At the DNA level, three of the eight codons encoding amino acids affected by gf mutations show synonymous codon substitution between $C$. elegans and C. briggsae.

One of the tra-1(gf) alleles examined, the weak atypical mutation $e 2271$ has a wild-type GF region. This is consistent with the suggestion that this allele, and other alleles that exhibit similar phenotypes (Zarkower et al. 1994), are distinct from the strong tra-1(gf) mutations described in Table 2 . These weak alleles probably define a minor site for tra-1 regulation that is as yet unidentified.

The tra-1(gf) mutations may identify a site for an inhibitory protein/protein interaction

The tra-1 (gf) mutations described in Table 2 behave genetically as constitutive for tra-1 activity, rather than 
A

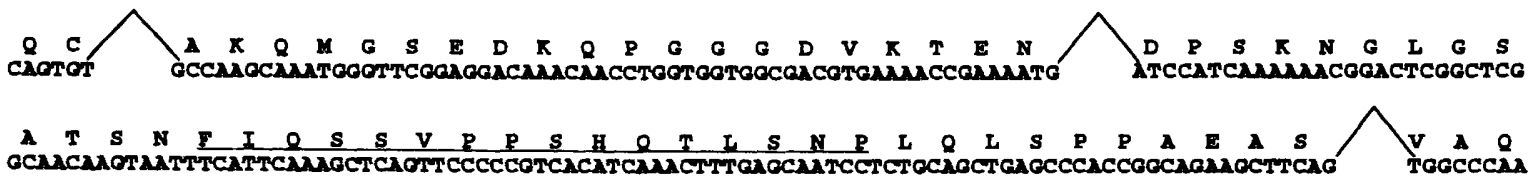

B

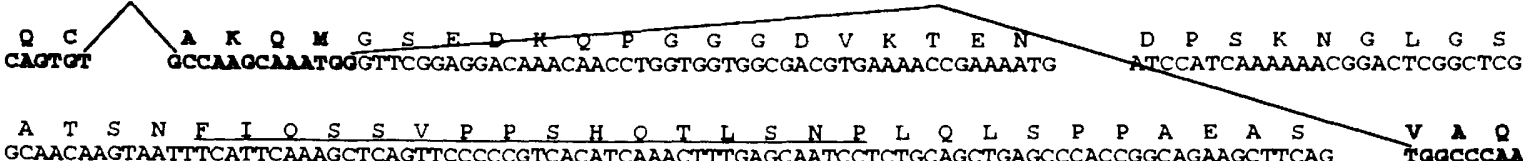

C

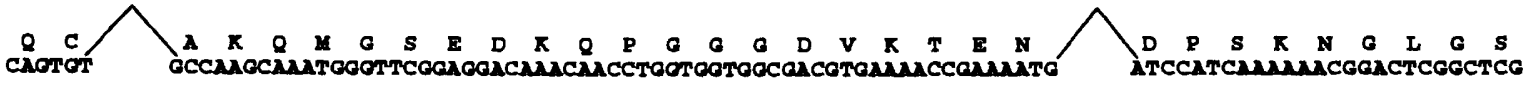

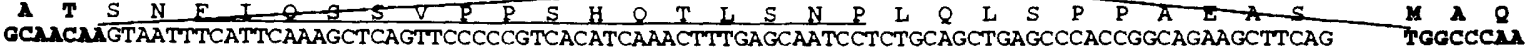

D

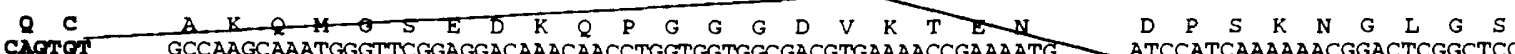
cAmor GCCAAGCAAATGGGTCGGAGGACAAACAACCTGGTGGTGGCGACGTGAAAACCGAAAATG ATCCATCAAAAAACGGACTCGGCTCG

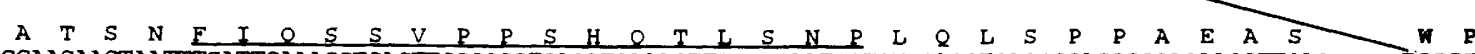
GCAACAAGTAATTTCATTCAAAGCTCAGTTCCCCCGTCACATCAAACTTTGAGCAATCCTCTGCAGCTGAGCCCACCGGCAGAAGCTTCAG

E

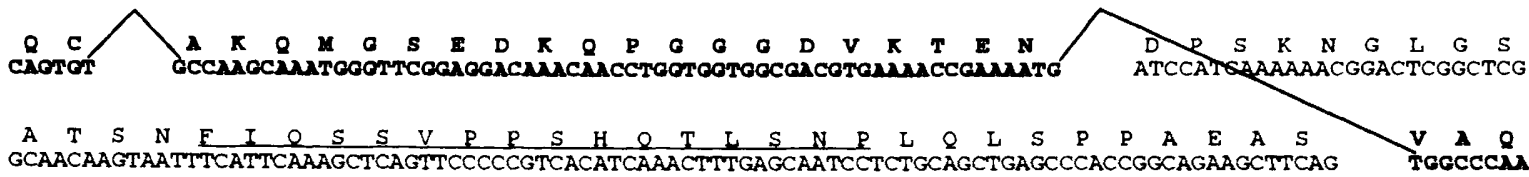

Figure 5. Splicing patterns of tra-1 RNA in tra-1(q245gf). This allele appears to be associated with a defective splice donor site in tra-1 exon 4, which encodes the GF region. This results in co-option of aberrant donor sites. $(A-E)$ The tra-1 splice products detected in $q 245$ cDNA. Nucleotide sequences included in cDNA products are shown in bold, as are the amino acid sequences that these products encode. The underlined amino acid sequence is the GF region. $(A)$ Wild-type splice; $(B, C)$ aberrant splices that delete the GF region and retain frame. The aberrant splice shown in $C$ also substitutes the first residue encoded by exon 5 , a valine, by a methionine. $(D)$ exon skipping that deletes exons 3 and 4 , and alters frame; $(E)$ exon skipping that deletes exon 4 and retains frame. An estimate of the relative abundance of these splice products is shown in Fig. 3.

hypermorphic (Hodgkin 1987). Their associated amino acid changes are therefore unlikely to be simply increasing tra-1 activity. Furthermore, the splicing mutations $q 185$ and $q 245$ appear to exert their effect by deleting the GF region, which is unlikely to increase the potency of TRA-1 as a transcriptional regulator (TRA-1 is used to indicate both protein products of tra-1). We suggest that the GF region defines a target site for negative regulation of TRA-1, probably by a protein-protein interaction and that tra-1(gf) mutations compromise or abolish this regulation. The allelic series described in Table 2 is explained by this model if the various amino acid substitutions associated with different tra-1(gf) alleles impair the inhibitory interaction to different extents. The splicing mutations $q 185$ and $q 245$ exert their effect by deleting part or all of the GF region and removing the inhibitor target site. The hydrophilicity of the GF region suggests that it may lie on the surface of the TRA-1 proteins, as might be expected for a site of protein interaction.

How might the GF region mediate negative regulation of TRA-1? In one scenario, the GF region defines a site for covalent modification of tra-1, for example, by phosphorylation. Alternatively, it may define a surface that interacts with a negative regulator of tra-1 to form a stable noncovalent complex. At present, molecular data about the sex determination pathway upstream of tra-1 are more consistent with a model in which a noncovalent protein interaction down-regulates TRA-1 activity (see below); however, the possibility remains that one or more of the serine/threonine residues in the GF region are the targets of a serine/threonine kinase. Inspection of the GF region reveals a glycogen synthase kinase-3 (GSK3) site identical to site $3 a$ in rabbit muscle glycogen synthase (the site is SVPPS*; Wang and Roach 1993; the underlined $S$ residue $(S)$ is phosphorylated by GSK-3 if the $S$ residue marked by an asterisk $\left(S^{*}\right)$ has been phosphorylated previously). One speculative possibility is that phosphorylation by GSK-3 at this site serves to modulate a protein interaction that inhibits TRA-1 activity or modulates activity directly. However none of the tra-1(gf) mutations characterized in this study substitute the serine residue predicted to be phosphorylated 
by GSK-3, although a serine to leucine change is easily feasible with EMS. Finally, we cannot exclude the possibility that the GF region does not define a site of interaction with a negative regulator but, rather, is indirectly required for negative regulation, for example, by allowing a protein conformational change.

\section{A molecular model for how the fem genes inhibit tra-1 activity}

A simple model that accounts for the phenotypes and lesions associated with the tra-1(gf) alleles is shown in Figure 6. In XO animals, the fem gene products are active. One or more of the FEM proteins, perhaps acting as a complex, interacts with the GF region of TRA-1 proteins and inhibits TRA-1 activity. A good candidate to interact physically with tra-1 is fem-1, as it contains six copies of the ANK repeat, a motif thought to mediate protein-protein interactions /Michaely and Bennett 1992). Down-regulation of TRA-1 permits male development. The absence or low level of FEM activity in XX animals allows the two protein products of tra-1, TRA1A and TRA-1B, to direct hermaphrodite development.

How might the proposed interaction between TRA-1 and FEM proteins down-regulate tra-1 activity? One pos-

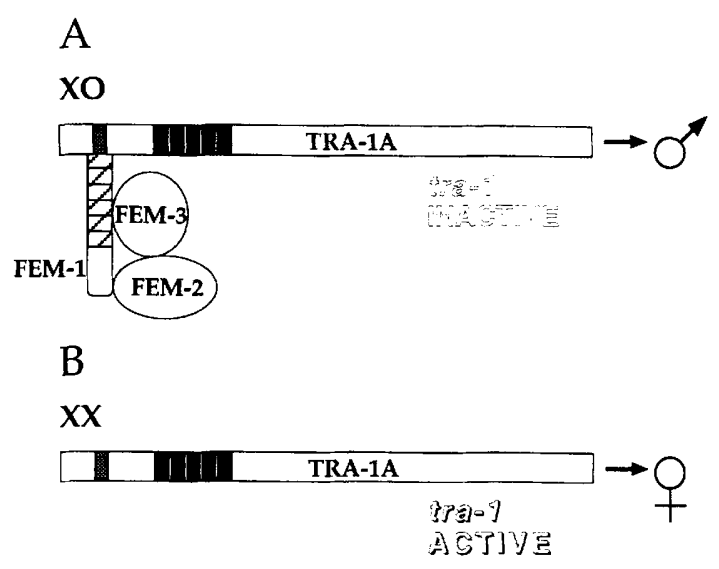

Figure 6. A speculative model for the sexual regulation of tra1. Shapes indicate protein products of sex-determining genes; solid boxes represent zinc fingers, stippled boxes, the GF region; hatching ANK repeats. $(A)$ In XO animals, the products of the fem genes, which are genetically defined negative regulators of tra-1, interact with the GF region and down-regulate TRA-1. (B) In the soma of XX animals, FEM activity is low, because of negative regulation by TRA-2. This allows TRA-1 to direct hermaphrodite development. FEM-1 is a good candidate to interact physically with TRA-1, as it contains six copies of the ANK repeat, a motif thought to mediate protein-protein interactions. For simplicity, the products of the three fem gene are shown acting in a complex, but there is no compelling evidence to distinguish this model from other models in which the fem products act in a linear pathway or in nonredundant parallel pathways to repress TRA-1. TRA-1B is not included in the model, as its functional relevance to tra-1 activity is unclear (see text); however, because it contains the GF region, it too could bind fem products. sibility is that the interaction prevents nuclear localization of TRA-1, as has been shown previously to occur

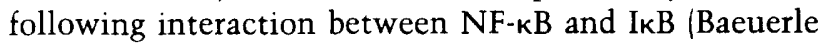
and Baltimore 1988a, b; Nolan et al. 1991). Alternatively, the interaction might destabilize TRA-1, alter or abolish its DNA binding ability, or otherwise affect its proposed function as a transcriptional regulator.

While TRA- $1 \mathrm{~A}$ is essential for tra-1 activity, the role of TRA-1B is unclear. Mutations that introduce stop codons in TRA-1A but not TRA-1B have strong tra-1(lf) phenotypes, suggesting that TRA-1B is unable to direct any female development on its own (Zarkower and Hodgkin 1992). The results described here suggest that TRA-1B, which contains the GF region, may play a regulatory role, by titrating away inhibitors of TRA-lA and potentiating its activity. The abundance of mRNA encoding TRA-1B during L1, L2, and L3 (the first, second, and third larval stages, when most sexual dimorphism is generated) may reflect a role TRA-1B plays as a "bodyguard" for TRA-1 A (Zarkower and Hodgkin 1992). However, results to date do not exclude the possibility that TRA-1B is an evolutionary accident, with no role in sex determination.

\section{The role of tra-1 in the germ line}

The role of tra-1 in somatic sex determination is straightforward: high tra-1 activity is necessary and sufficient for female development, low tra-1 activity is necessary and sufficient for male development. The role of tra-1 in the germ line is more complex: Although tra-1 regulates choice of germ-line sex, both oogenesis and spermatogenesis can occur in the complete absence of tra-1 activity.

The germ line of wild-type XO animals produces only sperm, whereas that of XX animals first produces sperm but then switches to making oocytes at the adult moult. $\mathrm{XX}$ and XO animals homozygous for tra-1(null) mutations have a male soma but make reduced amounts of sperm in their germ line; tra-1(null) $\mathrm{XX}$ animals also make oocytes occasionally (Hodgkin 1987, 1993; Schedl et al. 1989|. Therefore tra-1 activity is required for abundant spermatogenesis and to prevent oogenesis in animals that are somatically male.

Strong gf mutations of tra-1 cause severe germ-line feminization: Spermatogenesis is invariably abolished in tra-1(gf)/ + XX animals, and tra-1(gf)/ + XO germ lines usually produce many oocytes and few if any sperm ( Table 2; Hodgkin 1980, 1987). It has been difficult to rationalize why lf and gf mutations of tra-1 both feminize the germ line, as the molecular nature of the lesions associated with tra-1(gf) alleles was unknown. The molecular studies described in this work allow reassessment of this genetic data.

As discussed above, the simplest interpretation of tra1(gf) mutations is that they uncouple TRA-1 from regulation by the fem genes. The germ line phenotype of tra-1(gf) mutations implies that in wild-type animals, high fem gene activity prevents tra-1 from inhibiting sperm production in $\mathrm{XO}$ and $\mathrm{L} 4 \mathrm{XX}$ animals. This is not 
the only role of the fem genes in germ-line sex determination: tra-1(null); fem(lf) animals produce only oocytes, indicating that the fem genes are required for spermatogenesis irrespective of tra-1 activity. Inhibition of spermatogenesis by tra-1 may be important for correct execution of the sperm-to-oocyte switch at the adult moult of XX animals. The switch to oogenesis is thought to involve down-regulation of fem gene activity (Barton et al. 1987; Ahringer and Kimble 1991). Low fem activity would allow tra-1 to inhibit spermatogenesis and to reinforce the switch to oogenesis. The tra-1-mediated repression of spermatogenesis does not require tra-2 or tra-3, as for strong tra-1(gf) alleles, tra-1(gf); tra2(lf) and tra-1(gf); tra-3(lf) $\mathrm{XX}$ animals are still female. The targets of tra-1 regulation in germ line sex-determination have not yet been defined, and tra-1 could either repress spermatogenesis directly, or indirectly, by activating oogenesis.

A model for the role of tra-1 in germ-line sex determination is illustrated in Figure 7. In XO animals tra-1 is required for abundant spermatogenesis. In adult XX animals, tra-1 helps to inhibit spermatogenesis and activate oogenesis. These two roles of tra-1 appear contradictory, but can be reconciled, for example, if tra-1 activity is qualitatively altered by the presence of high levels of fem activity. During spermatogenesis, active fem genes may permit tra-1 to support abundant spermatogenesis; during oogenesis, the low level of fem activity may allow tra-1 to repress spermatogenesis.

The region defined by gf mutations of tra-1 may be conserved in GLI3, a gene implicated in Greig cephalopolysyndactyly syndrome

TRA-1 belongs to a growing family of proteins that includes the Drosophila segment polarity gene $\mathrm{ci}^{D}$ /Orenic et al. 1990) and the human proto-oncogene GLI (Kinzler et al. 1988). Members of this family have five consecutive zinc fingers that share $>60 \%$ amino acid identity and, where tested, show the same DNA-binding specificities in vitro (Kinzler and Vogelstein 1990; Tanimura et al. 1993; Zarkower and Hodgkin 1993). For the most part, the mechanisms by which these genes are regulated is unknown. One possibility is that this family, or a subset of its members, is regulated by a common mechanism. Members of the family have been inspected for sequences homologous to the GF region of TRA-1; of the proteins examined (GLI, Kinzler et al. 1988; GLI3, Ruppert et al. 1990; THP, Tanimura et al. 1993; $\mathrm{ci}^{D}$, Orenic et al. 1990; and odd-paired, Benedyk et al. 1994), only GLI3, a gene associated with Greig's syndrome in humans (Ruppert et al. 1990; Vortkamp et al. 1991) has a region similar to the TRA-1 GF region (Fig. 8). Of the eight residues in the GF region substituted in tra-1(gf) mutations, four are conserved in GLI3, and a fifth, a phenylalanine residue, is replaced by a tyrosine. There is no significant conservation of sequences immediately surrounding the GF region. Interspecific comparison of TRA-1 between $C$. elegans and C. briggsae, a closely related nematode, shows a similar pattern of conserva-
A

\section{XO (and LA XX animals?)}

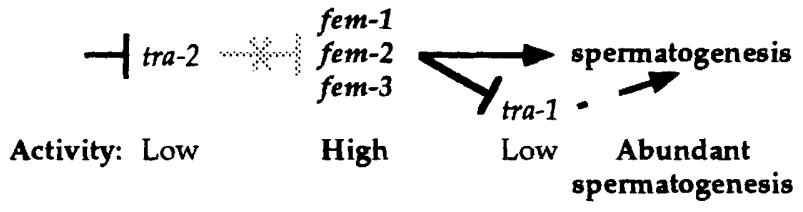

B

\section{Adult $\mathrm{XX}$ animals}

Activity: High Low High oogenesis

Figure 7. A model for the role of tra-1 in germ line sex-deter mination. Although tra-1 activity per se is not required for either germ line fate, this gene appears to modulate germ line sex determination. (A) In XO and L4 XX animals, high levels of fem activity down-regulate tra-1. However, in $\mathrm{XO}$ animals (and possibly in L4 XX animals|, tra-1 is still active at a low level which helps to prevent oogenesis and is necessary for abundant spermatogenesis. (B) If fem activity is low, tra-1 represses spermatogenesis and/or promotes oogenesis. Because the sperm-tooocyte switch in adult XX animals is thought to be initiated by a reduction in fem activity, tra-1 may help reinforce this switch. Arrows indicate activation; bars denote inhibition. Stippled bars and arrows are inoperative, as indicated by a cross. The effects of tra-1 on germ line sex are shown using broken arrows, to emphasize that tra-1 activity is not essential for the development of sperm or oocytes; however, active tra-1 does affect the choice of germ-line sex. The downstream targets by which tra-1 regulates germ line sex are unknown and may include fem genes. Activity refers to the activity state of each gene as inferred from mutant phenotypes. Note that low gene activity for tra-1 is distinct from complete absence of this activity.

tion: A region of 120 residues centered around the GF region shows only $25 \%$ identity between these two species, but all residues substituted in tra-1(gf) mutations are conserved (Fig. 8; M. de Bono and J. Hodgkin, unpubl.).

The GF-like region in GLI3 is situated at the same position relative to the highly conserved zinc fingers as the GF region in TRA-1A. However, the low level of sequence identity means the similarity may be fortuitous. Further experiments are required to investigate the significance of this site to GLI3 regulation.

A screen of $<1$ million EMS-mutagenized chromosomes may be sufficient to saturate the $\mathrm{C}$. elegans genome with $G C \rightarrow A T$ transitions

The seven different GC $\rightarrow$ AT transitions associated with tra-1(gf) mutations have each been found multiple 


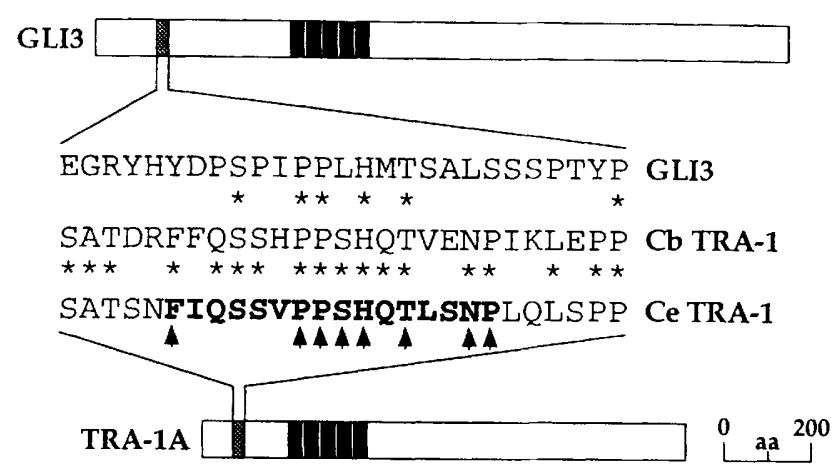

Figure 8. A comparison of the GF region of $C$. elegans $(\mathrm{Ce})$ and C. briggsae (Cb) TRA-1 with a similar sequence in GLI3. Sequence is given using the single-letter amino acid code, with the GF region in Ce TRA-1 shown in bold. Asterisks indicate amino acid identities, and arrowheads mark residues substituted in tra-1(gf) alleles. Boxes indicate protein sequence: solid boxes indicate zinc fingers; stippled boxes the GF region. The five zinc fingers of the GLI3 and of Ce TRA-1A show $65 \%$ amino identity, with fingers 3-5 80\% identical (Zarkower and Hodgkin 1992); however, the two proteins show no other obvious sequence homology. The GLI3 sequence is from Ruppert et al. (1990). A full description of Cb-tra-1 will be reported elsewhere.

times, in independently isolated alleles (Fig. 2). These multiple hits allow an estimate to be made of the number of chromosomes that need to be screened after standard EMS mutagenesis to saturate the $C$. elegans genome for such mutations. The data set used in this calculation is shown in Table 3. Assuming each $G$ residue has approximately the same likelihood of being modified by EMS, saturation for GC $\rightarrow$ AT transitions may be approached in screens of $\sim 1$ million EMS-mutagenized chromosomes. The assumption that each $G$ residue in the C. elegans genome is approximately equally reactive toward EMS is supported by data obtained in Escherichia coli (Coulondre and Miller 1977). These data, which con- sist of 680 mutations causing GC $\rightarrow$ AT substitutions at one of $26 \mathrm{G}$ residues of the lacI gene, show that the relative frequency of mutation at each of these residues never exhibits more than a fourfold difference from the average frequency, and usually shows less than a twofold difference. Although only approximate, the figure of 1 million is a useful guideline for the mutant selection screens possible in C. elegans. A calculation similar to the one above using data from studies of a multiply isolated fem-3(gf) lesion (Barton et al. 1987; Ahringer and Kimble 1991) gives a lower saturation estimate, of 360,000 EMS-mutagenized genomes. Our results also highlight the need to use a spectrum of mutagens to identify regulatory mutations: The heavy bias of EMS to generate GC $\rightarrow$ AT transitions probably precluded isolation of other nucleotide changes that would give a tra$1(g f)$ phenotype.

\section{What is the molecular mechanism underlying TRA-1 down-regulation?}

The results reported here strongly suggest that sexual regulation of the putative transcription factor(s) encoded by tra-1 occurs post-translationally: In XO animals, a protein interaction inhibits TRA-1 activity, thereby permitting male development. How might this be achieved, in mechanistic terms? Does the interaction cause TRA-1 to be degraded? Does it sequester TRA-1 to the cytoplasm? Does it alter or abolish TRA-1 DNA binding? Or does the interaction change the activity of TRA-1 as a transcriptional activator/repressor? Further studies are required to distinguish between these possibilities.

\section{Materials and methods}

General

Techniques for growth, handling, and microscopy of $C$. elegans have been described previously (Brenner 1974; Sulston and

Table 3. Screens of $10^{6}$ EMS-mutagenized genomes approach saturation of GC $\rightarrow$ AT transitions in C. elegans

\begin{tabular}{|c|c|c|c|c|}
\hline Mutagenesis experiment ${ }^{a}$ & Genomes screened & Alleles isolated & Lesion & Base change \\
\hline \multirow[t]{3}{*}{$0.05 \mathrm{M} \mathrm{EMS}, 4 \mathrm{hr}$} & 150,000 & e1946 & $\mathrm{CAT} \rightarrow \mathrm{TAT}$ & a \\
\hline & & $e 2013$ & $\mathrm{ACT} \rightarrow \mathrm{ATT}$ & $\mathrm{b}$ \\
\hline & & $e 2014$ & $\mathrm{TCA} \rightarrow \mathrm{TTA}$ & $\mathrm{c}$ \\
\hline \multirow[t]{5}{*}{$0.05 \mathrm{M} \mathrm{EMS}, 4 \mathrm{hr}$} & $\sim 700,000$ & e1951 & $\mathrm{CCT} \rightarrow \mathrm{CTT}$ & $\mathrm{d}$ \\
\hline & & e1962 & $\mathrm{CCC} \rightarrow \mathrm{CTC}$ & $\mathrm{e}$ \\
\hline & & e1997 & $\mathrm{TCA} \rightarrow$ TTA & c \\
\hline & & e1998 & $\mathrm{CCT} \rightarrow \mathrm{CTT}$ & d \\
\hline & & $e 2009$ & $\mathrm{CCG} \rightarrow \mathrm{TCG}$ & f \\
\hline \multirow[t]{4}{*}{$0.025 \mathrm{M} \mathrm{EMS}, 4 \mathrm{hr}$} & $\sim 100,000$ & $e 2065$ & $\mathrm{CCG} \rightarrow \mathrm{CTG}$ & $\mathrm{g}$ \\
\hline & & $e 2067$ & $\mathrm{CCG} \rightarrow \mathrm{CTG}$ & $\mathrm{g}$ \\
\hline & & $e 2069$ & $\mathrm{CCC} \rightarrow \mathrm{CTC}$ & $\mathrm{e}$ \\
\hline & & $e 2071$ & $\mathrm{CCC} \rightarrow \mathrm{CTC}$ & $\mathrm{e}$ \\
\hline
\end{tabular}

Total number of genomes screened:

950,000

${ }^{a}$ References are in Table 1.

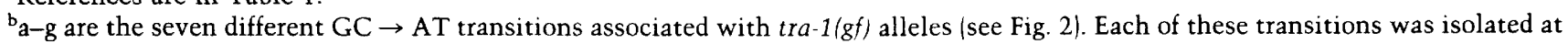
least once in the screens listed above: One lesion was isolated three times (e); three were isolated twice $(\mathrm{c}, \mathrm{d}$, $\mathrm{g})$; and the remaining three lesions were isolated once $(a, b, f)$. 
Hodgkin 1988). Strains were obtained from the Cambridge collection established by Brenner (1974), and are designated according to the nomenclature of Horvitz et al. (1979). Most tra-1(gf) alleles were maintained as tra-1(gf) $/+I I I$; tra-3(e1767) IV selffertile strains: The masculinizing effects of the tra-3 mutation partially suppress the germ-line feminization of $t r a-1(g f) /+$ animals and restore self-fertility (Hodgkin 1987). The exceptional alleles were $o z 6, q 183, q 185, q 245$, and $e 2271$. oz6 was maintained as tra-1(oz6gf)/ + III; tra-2(q276) II. The weak tra-1(gf) alleles $e 2271$ and $q 185$ were maintained as self-fertile homozygous strains. Heterozygotes for $q 183$ and $q 245$ are self-fertile hermaphrodites and were maintained as follows: q183 as unc32(e189) tra-1(q183gf)/qC1 $I I I ; q 245$ as tra-1(q245gf) dpy$18(e 364 \mathrm{am}) / e T 1 \mathrm{III} ; \mathrm{eT1} / \mathrm{V}$. unc signifies uncoordinated ${ }^{d} d p y$ signifies dumpy; $e T 1$ and $q C 1$ are rearrangements of chromosome III that suppress recombination in the region around unc32 , tra-1, and dpy-18.

\section{Characterization of tra-1 gf phenotypes}

Sexually dimorphic structures in tra-1(gf)/ $+\mathrm{XO}$ animals were examined by Nomarski microscopy at $1000 \times$ to determine whether they were female, male, or other. Animals were scored as young adults. Detailed descriptions of wild-type sexually dimorphic anatomy can be found in Hodgkin (1988), Kimble and Hirsh (1979), Sulston et al. (1980), and White (1988).

Animals doubly mutant for tra-1(gf) alleles and tra-2(lf) alleles were constructed as described in Hodgkin (1980). Two strong tra-1(gf) alleles were examined: $e 1575$ and $e 1946$. The tra-2(lf) allele used was the putative null mutation e1095. Sperm production in tra-2(e1095); tra-1/gf) and tra-2(e1095); tra-1(gf) $/+\mathrm{XX}$ animals was determined by measuring self-fertility, and by Nomarski examination. Heterozygous and homozygous tra-1(gf) animals were distinguished by progeny testing after crossing with wild-type males: tra-2; tra-1(gf) animals yield only female cross progeny; tra-2; tra-1(gf)/+ animals yield females and wild-type males.

\section{Generation of $c D N A$ from tra-l(gf) alleles}

For sequencing purposes, it was important to isolate RNA that contained only tra-1(gf) RNA. Most tra-1(gf) alleles cannot be maintained as homozygous strains and tra-1(gf) animals are sometimes difficult to distinguish phenotypically from their tra-1(gf)/ + siblings. Total RNA was therefore isolated from XX worms of the following genotypes. (1) q185, e2271: from strains homozygous for these alleles. (2) q183, q245: from marked tra$1(g f)$ homozygotes generated from the balanced strains described above, i.e., unc-32(e189) tra-1 (q183gf) and tra-1(q245gf) dpy-18(e364am). (3) e1575, e1937, e1946, e1951, e1953, e1961, e1962, e1997, e2009, e2013, e2014, e2065, e2069, e2109, e2535, $e 2537, e 2554, e 2579$, and oz6: from worms that were tra-1(gf)/ tra-1(e1834). The tra-1 allele $e 1834$ is a molecularly defined null mutation that deletes $17 \mathrm{~kb}$ of $t r a-1$, including the putative promoter and the amino-terminal half of the tra-1 open reading frame, which contains the GF region (Zarkower and Hodgkin 1992; Hodgkin 1993). Worms of this genotype were obtained by mating e1834 XX males with putative tra-1(gf); tra-3(e1767) XX females (or for oz6, with tra-1(oz6gf); tra-2(e1095) XX females). All progeny from this cross should be females of tra-1 genotype tra-1(gf)/tra-1(e1834); the absence of any self-fertility in these animals confirms the absence of a tra-1(+) gene in the female parent, which would yield tra-1(+)/tra-1(lf) self-fertile hermaphrodites. (4) e1993, e1998, e2067, e2071, e2097, e2098, e2198: For these mostly weaker alleles, it was found that careful analysis of tail and germ-line phenotypes allowed tra-1(gf); tra- 3(e1767) worms to be distinguished from their tra-1(gf)/+ ; tra3(e1767) siblings. The tra-1/gf)/t; tra-3(e1767) worms have truncated tail spikes and are frequently self-fertile hermaphrodites, because of masculinization by the tra-3(lf) mutation; in contrast, tra-1(gf); tra-3(e1767) animals are females with a wildtype tail spike.

For each allele, 40-50 worms of the required genotype were hand-picked into $1 \mathrm{ml}$ of $\mathrm{M} 9$ buffer in a 1.5-ml Eppendorf tube and spun at $6500 \mathrm{rpm}$ for $30-60 \mathrm{sec}$. The M9 supernatant was removed, and $0.5 \mathrm{ml}$ of proteinase $\mathrm{K}$ buffer was added (proteinase $\mathrm{K}$ buffer was $50 \mathrm{mM} \mathrm{NaCl}, 50 \mathrm{mM}$ Tris- $\mathrm{Cl}$ at $\mathrm{pH} 7.5,5 \mathrm{~mm}$ EDTA, $0.5 \%$ SDS, $40 \mathrm{mg} / \mathrm{ml}$ of glycogen, and $50 \mathrm{mg} / \mathrm{ml}$ of proteinase $\mathrm{K}$ ). The worms were digested with proteinase $\mathrm{K}$ for $\mathrm{l}$ $\mathrm{hr}$ at $50^{\circ} \mathrm{C}$, cooled to room temperature, and extracted twice with phenol-chloroform. The aqueous supernatant was made $0.2 \mathrm{M}$ in $\mathrm{NaCl}$, and nucleic acid was precipitated by addition of 2 volumes of ethanol, incubation on dry ice for $30 \mathrm{~min}$, and centrifugation at $12,000 \mathrm{rpm}$ for $15 \mathrm{~min}$. After washing with $70 \%$ ethanol, the nucleic acid pellet was dried for 5 min, resuspended in $15 \mu \mathrm{l}$ of water, and applied to a Sephadex G50 coarse (Pharmacia) spin column. Five microliters of the flow through was reverse transcribed in a $20 \mu \mathrm{l}$ reaction using AMV reverse transcriptase (HT) and random hexamer primers (Pharmacia). The resulting cDNA was used as substrate in PCR reactions that amplified portions of tra-1. Standard PCR protocols were used (Innis et al. 1989). The annealing temperature for all PCR reactions was $55^{\circ} \mathrm{C}$. The primers used are listed below. SLl, GGTTTAATTACCCAAGTTTGAG; MDB4, AGAATGTGCCAGGAGGCTC--forward primer from nucleotide 23; MDB13, GAACTCGAGTGGGTGGAATAAGGTGGAGCTTG-forward primer from nucleotide 234; DZ4, GCCGGTGGGCTCAGCTGCAGAGGATTGC-reverse primer from nucleotide 443; DZ5, GGCACAATTGACGATGTCGACGCGGAGG-reverse primer from nucleotide 590 ; DZ7, CATATCCGAATCATTTCCACTGTTCG-reverse primer from nucleotide $765 ; \mathrm{DZ} 10$, CTCGAGTTACCCAAGTTTGAGAGAATG-forward primer containing part of SL1 and the first 6 nucleotides of tra-1; DZ17, GCGTGATGTTCTTGTTCAGTTGATTGGAC-reverse primer from nucleotide 887; DZ31, GAATGTGTACGATTCTGATG-reverse primer from nucleotide 1154; DZ83, CATCATATGAGTTTGGAGC-reverse primer from nucleotide 1587; DZ93, GTTGAACCTGTGCCTGCATCTG-reverse primer from nucleotide 1636. The numbering system used to locate primers on the tra-1 cDNA sequence, as well as the sequence itself, can be found in Zarkower and Hodgkin (1992). Restriction sites present in primers are underlined.

\section{Identifying lesions associated with tra-l(gf) alleles}

el575 Fine-structure genetic mapping (Hodgkin 1987) demonstrated that the lesion associated with tra-1(e1575gf) was to the right of the 1099 nonsense mutation on the genetic map $\left(5^{\prime}\right.$ to $e 1099$ in the direction of transcription). We therefore sequenced tra-1 cDNA from N2, from e1575, and from the tra-1 amber alleles e1849tr and e1825tr (obtained as suppressors of $e 1575$ Hodgkin 1987) in the coding region $5^{\prime}$ to the position of $e 1099$. All except $\mathrm{N} 2$ had the same AT $\rightarrow$ GC transition. tra-1 cDNA was obtained by nested PCR of total CDNA, using PCR primers SL1 and DZ93, and nesting with primers DZ10 and DZ83. These primers amplify cDNA that encodes the amino-terminal 500 amino acids of TRA-1A. PCR products were run on a $0.7 \%$ agarose gel, extracted from the gel using Geneclean II (Bio 101), and sequenced directly by linear amplification PCR sequencing (Craxton 1991). This method avoids PCR-induced mutations. The sequencing primer used was DZ5. 
e1946, e1951, e1953, e1961, e1962, e1997, e2009, e2013, e2014, e2109, e2535, e2554, e2579, e2271 These alleles were sequenced essentially using the procedure described for $e 1575$, except that cDNA from each of these alleles was amplified by PCR using primer pairs MDB4 and DZ17 or MDB13 and DZ17. These primers amplify cDNA that encodes the amnio-terminal 250 amino acids of both TRA-1 proteins. The sequencing primers used were DZ4, DZ5, and DZ7.

e1937, e1961, e1993, e1998, e2065, e2067, e2069, e2071, e2097, e2098, e2198, e2537, oz6, q183, q185, q245 Total cDNA from each of these alleles was amplified using nested PCR (primers MDB13 and DZ31, followed by MDB13 and DZ17). For all alleles except $q 185$ and $q 245$, a single PCR product was obtained in this reaction. The PCR products were run on a $0.7 \%$ agarose gel, the DNA purified using Geneclean II (Bio 101), and cloned into Bluescript (BSSK $^{+}$, Stratagene) using the XhoI site in MDB13 and the SpeI site within the first zinc finger of tra-1 (Zarkower and Hodgkin 1992). A total of at least three clones from two independent PCR reactions were sequenced for each allele, to ensure that identified lesions were not PCR induced. For the splice acceptor mutants $q 185$ and $q 245$, several PCR products were obtained in the nested reactions described above (Fig. 3). These PCR products were not separated on an agarose gel, but directly purified using Geneclean II (Bio 101) and cloned as above; 29 independent clones were sequenced for $q 185$, and 10 for $q 245$. Sequencing was by the chain termination method of Sanger et al. (1977) using Sequenase 2.0 DNA polymerase (U.S. Biochemical), and double-stranded templates were prepared by alkaline lysis (Sambrook et al. 1989).

The large size of $t r a-1 \mid>20 \mathrm{~kb}$ of genomic DNA; $5 \mathrm{~kb}$ of cDNA) precludes comprehensive sequencing of the gene in tra$1(g f)$ alleles, and it remains possible that second site mutations in tra-1 modify the phenotypes of the tra-1(gf) lesions described. However, no phenotypic differences have been detected between independently isolated tra-1(gf) alleles associated with the same base changes.

\section{Acknowledgments}

We are grateful to M.K. Barton, T. Doniach, J. Kimble, and T. Schedl for generously donating some of the tra-1(gf) alleles. J. Ahringer and $\mathrm{M}$. Bretscher kindly commented on the manuscript. M.d.B acknowledges studentships from the Wellcome Trust and the Overseas Research Studentship Awards Scheme. D.Z. was supported by postdoctoral fellowships from the Helen Hay Whitney Foundation and the American Cancer Society. J.H. is an International Research Scholar of the Howard Hughes Medical Institute.

The publication costs of this article were defrayed in part by payment of page charges. This article must therefore be hereby marked "advertisement" in accordance with 18 USC section 1734 solely to indicate this fact.

\section{References}

Ahringer, J. and J. Kimble. 1991. Control of the sperm-oocyte switch in Caenorhabditis elegans by the fem-3 $3^{\prime}$ untranslated region. Nature 349: 346-348.

Ahringer, J., T.A. Rosenquist, D.N. Lawson, and J. Kimble. 1992. The Caenorhabditis elegans sex-determining gene fem-3 is regulated post-transcriptionally. EMBO J. 11:23032310.

Aroian, R.V., A.D. Levy, M. Koga, Y. Ohshima, J.M. Kramer, and
P.W. Sternberg. 1993. Splicing in Caenorhabditis elegans does not require an $\mathrm{AG}$ at the $3^{\prime}$ splice acceptor site. Mol. Cell Biol. 13: 626-637.

Baeuerle, P.A. and D. Baltimore. 1988a. Activation of DNAbinding activity in an apparently cytoplasmic precursor of the NF- $\mathrm{kB}$ transcription factor. Cell 53: 211-217.

1988b. I $\mathrm{KB}$ : A specific inhibitor of the NF- $\mathrm{kB}$ transcription factor. Science 242: 540-546.

Barton, M.K., T.B. Schedl, and J. Kimble. 1987. Gain-of-function mutations of fem-3, a sex-determining gene in Caenorhabditis elegans. Genetics 115: 107-119.

Benedyk, M.J., J.R. Mullen, and S. DiNardo. 1994. odd-paired: A zinc finger pair-rule protein required for the timely activation of engrailed and wingless in Drosophila embryos. Genes \& Dev. 8: 105-117.

Brenner, S. 1974. The genetics of Caenorhabditis elegans. Genetics 77: 71-94.

Coulondre, C. and I.H. Miller. 1977. Genetic studies of the lac repressor: IV. Mutagenic specificity in the lacI gene of Escherichia coli. J. Mol. Biol. 117: 577-606.

Craxton, M. 1991. Linear amplification sequencing, a powerful method for sequencing DNA. Methods: Companion Methods Enzymol. 3: 20-26.

Doniach, T. and J. Hodgkin. 1984. A sex-determining gene, fem1 , required for both male and hermaphrodite development in Caenorhabditis elegans. Dev. Biol. 106: 223-235.

Hodgkin, J. 1980. More sex-determination mutants of Caenorhabditis elegans. Genetics 96: 649-664.

1985. Novel nematode amber suppressors. Genetics 111: $287-310$.

- 1986. Sex determination in the nematode C. elegans: Analysis of tra-3 suppressors and characterization of fem genes. Genetics 114: 15-52.

1987. A genetic analysis of the sex-determining gene, tra-1, in the nematode Caenorhabditis elegans. Genes \& Dev. 1: 731-745.

-1988. Sexual dimorphism and sex determination. In The nematode Caenorhabditis elegans (ed. W.B. Wood), pp. 243 280. Cold Spring Harbor Laboratory, Cold Spring Harbor, New York.

- 1993. Molecular cloning and duplication of the nematode sex determining gene tra-1. Genetics 133: 543-560.

Horvitz, H.R., S. Brenner, J. Hodgkin, and R.K. Herman. 1979. A uniform genetic nomenclature for the nematode Caenorhabditis elegans. Mol. \& Gen. Genet. 175: 129-133

Hunter, C.P. and W.B. Wood. 1990. The tra-1 gene determines sexual phenotype cell-autonomously in C. elegans. Cell 63: 1193-1204.

1992. Evidence from mosaic analysis of the masculiniz ing gene her-1 for cell interactions in C. elegans sex deter mination. Nature 355: 551-555.

Innis, M.A., D.H. Gelfland, J.J. Sninsky, and T.J. White. 1989. PCR protocols: $A$ guide to methods and applications. Academic Press, San Diego, CA.

Kimble, I., and D. Hirsh. 1979. The post-embryonic cell lineages of the hermaphrodite and male gonads in Caenorhabditis elegans. Dev. Biol. 70: 396-417.

Kimble, J., L. Edgar, and D. Hirsh. 1984. Specification of male development in Caenorhabditis elegans: The fem genes. Dev. Biol. 105: 234-239.

Kinzler, K.W. and B. Vogelstein. 1990. The GLI gene encodes a nuclear protein which binds specific sequences in the human genome. Mol. Cell. Biol. 10: 634-642.

Kinzler, K.W., J.M. Ruppert, S.H. Bigner, and B. Vogelstein. 1988. The GL1 gene is a member of the Kruppel family of zinc finger proteins. Nature 332: 371-374. 
Kuwabara, P.E. and J. Kimble. 1992. Molecular genetics of sex determination in C. elegans. Trends Genet. 8: 164-168.

Kuwabara, P.E., P.G. Okkema, and J. Kimble. 1992. The tra-2 gene encodes a membrane protein and may mediate cell communication in the $C$. elegans sex determination pathway. Mol. Biol. Cell 3: 461-473.

Madl, J.E. and R.K. Herman. 1979. Polypoids and sex determination in Caenorhabditis elegans. Genetics 93: 393-402.

Michaely, P. and V. Bennett. 1992. The ANK repeat: A ubiquitous motif involved in macromolecular recognition. Trends Cell Biol. 2: 127-129.

Nigon, V. 1951. Polyploidie experimentale chez un nematode libre, Rhabditis elegans Maupas. Bull. Biol. Fr. Belg. 85: 187-225.

Nolan, G.P., S. Ghosh, H-C. Liou, P. Tempst, and D. Baltimore. 1991. DNA binding and IKB inhibition of the cloned p65 subunit of NF-кB, a rel-related polypeptide. Cell 4: 961-969.

Okkema, P.G. and J. Kimble. 1991. Molecular analysis of tra-2, a sex-determining gene in C. elegans. EMBO 1. 10: 171-176.

Orenic, T. V., D.C. Slusarski, K.L. Kroll, and R.A. Holmgren. 1990. Cloning and characterization of the segment polarity gene cubitus interruptus Dominant of Drosophila. Genes \& Dev. 4: 1053-1067.

Parkhurst, S.M. and P.M. Meneely. 1994. Sex determination and dosage compensation: Lessons from flies and worms. Science 264: 924-932.

Perry, M.D., W. Li, C. Trent, B. Robertson, A. Fire, J.M. Hageman, and W.B. Wood. 1993. Molecular characterization of the her-1 gene suggests a direct role in cell signaling during Caenorhabditis elegans sex determination. Genes \& Dev. 7: 216-228.

Pulak, R. and P. Anderson. 1993. Messenger RNA surveillance by the Caenorhabditis elegans smg genes. Genes \& Dev. 7: 1885-1897.

Ruppert, J.M., K.W. Kinzler, A.J. Wong, S.H. Bigner, F-T. Kao, M.L. Law, H.N. Seuanez, S.J. O'Brian, and B. Vogelstein. 1988. The GLI-Kruppel family of human genes. Mol. Cell. Biol. 8: 3104-3113.

Ruppert, J.M., B. Vogelstein, K. Arheden, and K.W. Kinzler. 1990. GLI3 encodes a 190-kilodalton protein with multiple regions of GLI similarity. Mol. Cell Biol. 10: 5408-5415.

Sambrook, J., E.F. Fritsch, and T. Maniatis. 1989. Molecular cloning: A laboratory manual. Cold Spring Harbor Laboratory, Cold Spring Harbor, New York.

Sanger, F., S. Nicklen, and A.R. Coulson. 1977. DNA sequencing with chain-terminating inhibitors. Proc. Natl. Acad. Sci. 74: 5463-5467.

Schedl, T., P.L. Graham, M.K. Barton, and J. Kimble. 1989. Anal$y$ sis of the role of tra-1 in germ-line sex determination in the nematode Caenorhabditis elegans. Genetics 123: 755-769.

Spence, A.M., A. Coulson, and J. Hodgkin. 1990. The product of fem-1, a nematode sex-determining gene, contains a motif found in cell cycle control proteins and receptors for cell-cell interactions. Cell 60: $981-990$.

Sulston, J. and J. Hodgkin. 1988. Methods. In The nematode Caenorhabditis elegans (ed. W.B. Wood), pp. 587-606. Cold Spring Harbor Laboratory, Cold Spring Harbor, New York.

Sulston, J.E. and H.R. Horvitz. 1977. Post-embryonic cell lineages of the nematode Caenorhabditis elegans. Dev. Biol. 56: $110-156$.

Sulston, J.E., D.G. Albertson, and J.N. Thomson. 1980. The Caenorhabditis elegans male: Postembryonic development of nongonadal structures. Dev. Biol. 78: 542-576.

Sulston, J.E., E. Schierenberg, J.G. White, and J.N. Thomson. 1983. The embryonic cell lineage of the nematode Caenorhabditis elegans. Dev. Biol. 100: 64-119.
Tanimura, A., H. Teshima, I.-I. Fujisawa, and M. Yoshida. 1993 A new regulatory element that augments the Tax-dependent enhancer of human T-cell leukemia virus type 1 and cloning of cDNAs encoding its binding proteins. /. Virol. 67: 53755382 .

Trent, C., B. Purnell, S. Gavinski, J. Hageman, C. Chamblin, and W.B. Wood. 1991. Sex-specific transcriptional regulation of the $C$. elegans sex-determining gene her-1. Mech. Dev. 34: 43-56.

Villeneuve, A.M. and B.J. Meyer. 1990. The regulatory hierarchy controlling sex determination and dosage compensation in Caenorhabditis elegans. Adv. Genet. 27: 117-188.

Vortkamp, A., M. Gessler, and K.-H. Grzeschik. 1991. GLI3 zinc finger gene interrupted by translocations in Greig syndrome families. Nature 352: 339-340.

Wang, Y. and P.J. Roach. 1993. Inactivation of rabbit muscle glycogen synthase by glycogen synthase kinase-3. $/$. Biol. Chem. 268: 23876-23880.

White, J. 1988. The anatomy. In The nematode Caenorhabditis elegans (ed. W.B. Wood), pp. 81-122. Cold Spring Harbor Laboratory, Cold Spring Harbor, New York.

Zarkower, D. and J. Hodgkin. 1992. Molecular analysis of the $C$. elegans sex-determination gene tra-1: A gene encoding two zinc finger proteins. Cell 70: 237-249.

1993. Zinc fingers in sex determination: Only one of the two C. elegans Tra-1 proteins binds DNA in vitro. Nucleic Acids Res. 21: 3691-3698.

Zarkower, D., M. de Bono, R. Aronoff, and J. Hodgkin. 1994. Regulatory rearrangements and smg-sensitive alleles of the C. elegans sex determining gene tra-1. Dev. Genet. 15: 240250 . 


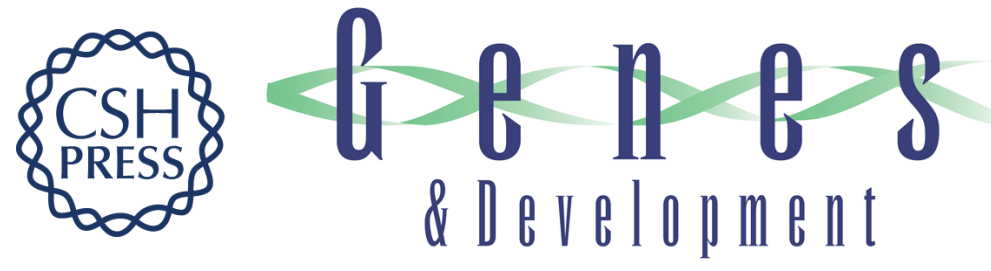

\section{Dominant feminizing mutations implicate protein-protein interactions as the main mode of regulation of the nematode sex-determining gene tra-1.}

M de Bono, D Zarkower and J Hodgkin

Genes Dev. 1995, 9:

Access the most recent version at doi:10.1101/gad.9.2.155

References This article cites 50 articles, 23 of which can be accessed free at: http://genesdev.cshlp.org/content/9/2/155.full.html\#ref-list-1

License

Email Alerting Service

Receive free email alerts when new articles cite this article - sign up in the box at the top right corner of the article or click here.

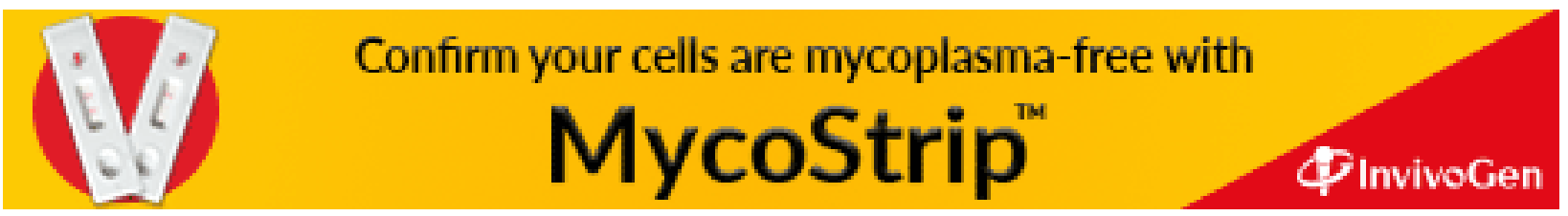

